\title{
A FILIAÇÃO SOCIOAFETIVA E SEUS REFLEXOS NO ORDENAMENTO JURÍDICO BRASILEIRO
}

\author{
Tamiris Aparecida Rangel Siqueira ${ }^{1}$ \\ Ricardo Spinelli Pinto ${ }^{2}$
}

\section{RESUMO}

O objetivo do presente trabalho é analisar a relevância da filiação socioafetiva e discutir os reflexos do seu reconhecimento no sistema jurídico brasileiro. Devido às mudanças sociais ocorridas na sociedade, o Direito de Família passou a valorizar os laços afetivos existentes entre pais e filhos, e passou a reconhecer uma nova modalidade de filiação, a filiação socioafetiva. Filiação socioafetiva é aquela filiação pautada na convivência familiar, na solidariedade, no amor entre pais e filhos, sem que exista necessariamente vínculo biológico ou jurídico entre eles. Apresenta-se em diversas situações, como na adoção legal, na adoção à brasileira, nos filhos de criação e nos filhos provenientes de técnicas de reprodução assistida heteróloga. A pesquisa foi desenvolvida através do estudo teórico de doutrinas, e de jurisprudências a respeito do tema em pauta. O reconhecimento da filiação socioafetiva gera efeitos pessoais e efeitos que vão além da relação entre pais e filhos, como no caso da inelegibilidade do filho socioafetivo. Assim, o Supremo Tribunal Federal reconheceu a repercussão geral do tema da prevalência ou não dessa modalidade de filiação. A criação da Lei 11.924/2009 que autorizou o acréscimo do patronímico do padrasto ou madrasta no registro de nascimento é um reflexo que a filiação socioafetiva ocasionou na legislação. E a multiparentalidade, é uma direção que aos poucos tem sido tomada pelos operadores de direitos a fim de

\footnotetext{
${ }^{1}$ Graduada em Direito pelas Faculdades Integradas Vianna Júnior.

${ }^{2}$ Graduação em Direito pela Universidade Federal de Juiz de Fora, UFJF. Especialização Lato Sensu. Faculdades Integradas Vianna Junior. Professor do Curso de Direito das Faculdades Integradas Vianna Junior. Professor do Curso Técnico de Segurança Pública da Polícia Militar de Minas Gerais.
} 


\section{VIANNA SAPIENS}

dar efetividade a todos os laços afetivos existentes no âmbito familiar.

PALAVRAS-CHAVE: FAMÍLIA. FILIAÇÃO. SOCIOAFETIVA. AFETIVIDADE. MULTIPARENTALIDADE.

\section{INTRODUÇÃO}

A presente pesquisa analisa a filiação socioafetiva, modalidade de parentesco civil fundado no elo da afetividade, bem como na posse de estado de filho. Tem alicerce no artigo 1593 do Código Civil Brasileiro, que ao instituir a expressão "outra origem" reconhece o parentesco civil de origem afetiva. A filiação socioafetiva é também reconhecida pelo Direito de Família à luz dos princípios da dignidade da pessoa humana, do princípio do melhor interesse da criança e do adolescente, da afetividade e da solidariedade.

Diferentemente do que se observa no contexto contemporâneo, o Código Civil de 1916 estabelecia um conceito estrito de filiação, onde somente era filho aquele que se amoldava na legitimidade delineada pelo Código. Prevalecia à determinação jurídica, pautada na presunção pater is est, sendo filho detentor de todos os direitos e deveres inerentes à filiação, somente aquele nascido na constância do casamento, desprezava-se o vínculo afetivo e biológico.

Mais tarde, com a evolução da ciência e a possibilidade de descobrir o vínculo genético através do exame de DNA, ocorreu a supervalorização do elo biológico, sendo pai e mãe aqueles que possuíam o mesmo material genético do filho.

Todavia, mesmo com o Código Civil de 2002 repetindo a presunção pater is est, e a possibilidade de descobrir o liame biológico, percebe-se que nem sempre estes pais constituídos pelo vínculo presumido ou biológico exercem efetivamente as funções da paternidade e da maternidade. Desta forma foi necessário reconhecer outra vertente da filiação, aquela baseada no vínculo socioafetivo estabelecido através da convivência familiar. 


\section{VIANNAS SAPIENS}

edição especial
iz de Fora - 2014

Diante dessas considerações, o objetivo geral desta pesquisa é avaliar a importância da filiação socioafetiva e os reflexos do seu reconhecimento no ordenamento jurídico brasileiro, que vem sendo objeto de frequentes discussões em nossos tribunais e em diversas doutrinas.

Esta pesquisa foi desenvolvida através do estudo teórico com doutrinas especializadas, e do estudo de casos jurisprudenciais em que se discute o reconhecimento da filiação fundada no afeto e suas consequências jurídicas e pessoais.

O estudo analisa as espécies de filiação existentes no ordenamento jurídico contemporâneo e apresenta as consequências que o reconhecimento da filiação social e afetiva acarretou no ordenamento jurídico.

\section{ESPÉCIES DE FILIAÇÃO NA ATUAL ORDEM CONSTITUCIONAL}

Os artigos 227 § 6 da Constituição Federal e 1.596 do Código Civil de 2002 estabelecem a igualdade integral entre todos os filhos, não fazendo quaisquer discriminações. Porém, para fins de análise da filiação socioafetiva sob seus aspectos mais relevantes, se mostra necessário abordar o atual quadro disposto no Código, com um viés constitucional.

A filiação jurídica é aquela que a lei determina. Ou seja, é o vínculo constituído entre pais e filhos respaldados pela legislação.

Nessa vertente, o código atual prevê formas de presunções de paternidade quanto aos filhos nascidos na constância do matrimônio, denominada presunções pater is est.

De acordo com o artigo 1.597 e seus incisos, presume serem filhos aqueles nascidos "cento e oitenta dias, pelo menos, depois de estabelecida a convivência conjugal", "nascidos nos trezentos dias subsequentes à dissolução da sociedade conjugal, por morte, separação judicial, nulidade e anulação do casamento".

Incorporando as novidades ocorridas na ciência, o código estabelece também a presunção filial daqueles nascidos através de fecundação artificial homóloga, até 
mesmo se o marido estiver falecido, e se tratando de embriões excedentários, aqueles nascidos a qualquer tempo.

Por fim, dispõe sobre a presunção do filho nascido através de inseminação artificial heteróloga, desde que o marido tenha autorizado previamente.

Quanto aos filhos nascidos fora do casamento, o reconhecimento se estabelece mediante ato voluntário ou através processo judicial, sendo ato irrevogável, como dispõe artigo 1.609 do Código Civil. ${ }^{3}$

A filiação biológica, por outro lado, é aquela pautada no vínculo genético entre pai e filho ou mãe e filho. Foi com a evolução da ciência e a descoberta de exames genéticos, particularmente do exame de DNA (ácido desoxirribonucleico), que ocasionou essa certeza do liame biológico e consequentemente rompeu com a exclusividade da presunção de filiação.

Ressalta-se, assim como fez Carvalho (2012) a relevância do exame de DNA, principalmente para aqueles que não possuíam nenhum pai.

No entanto, a composição dessa verdade biológica, nem sempre se revelou apta a assegurar uma filiação correspondente com a idealizada pela nossa Constituição Federal de 1988, baseada na dedicação, ampla assistência, solidariedade e fundada no princípio da Dignidade da Pessoa Humana.

$\mathrm{Na}$ lição de Leila Maria Torraca de Brito, 2008 (apud CARVALHO, 2012, p.104):

um aspecto é reconhecer que o progresso da genética traz fim à ideia de pai desconhecido, outro é utilizar o resultado desses exames para negar filiações constituídas, reconhecidas socialmente, firmadas publicamente por vontade.

Destarte, conforme essa certeza consanguínea mostrava-se insuficiente para respaldar a realidade fática, foi necessário valorizar outros elementos que definissem uma verdadeira relação familiar que estivessem de acordo com a constitucionalização do direito civil.

Tem-se então a filiação socioafetiva, fundada no elo da afetividade,

\footnotetext{
${ }^{3}$ O artigo 1.609, caput do Código Civil de 2002 dispõe que: "O reconhecimento dos filhos havidos fora do casamento é irrevogável [...]."
} 
decorrente de uma convivência familiar, da relação de amor, carinho, preocupação, dedicação, doação.

O Código Civil não reconheceu de forma explícita a filiação socioafetiva, porém, como bem assinala Dias (2011) em seu artigo $1.593^{4}$ instituiu o parentesco civil resultante de "outra origem", o que deu alicerce para o prestígio de outras maneiras de parentesco civil, sem ser a adoção. Nesse sentido, foram aprovados na primeira Jornada de Direito Civil os enunciados no 103 e nำ108, in verbis:

№ 103: O Código Civil reconhece, no artigo 1.593, outras espécies de parentesco civil além daquele decorrente da adoção, acolhendo, assim, a noção de que há também parentesco civil no vínculo parental proveniente quer das técnicas de reprodução assistida heteróloga relativamente ao pai (ou mãe) que não contribuiu com seu material fecundante, quer da paternidade socioafetiva, fundada na posse de estado de filho.

№ 108: No fato jurídico do nascimento, mencionado no artigo 1.603, compreende-se à luz do disposto no art. 1.593, a filiação consanguínea e também a socioafetiva.

E na terceira Jornada de Direito Civil, foi aprovado o enunciado no 256 que dispõe que "a posse de estado de filho (parentalidade socioafetiva) constituiu modalidade de parentesco civil".

Encontra-se também, implicitamente, o vínculo socioafetivo na adoção legal e formalizada, pois a adoção nada mais é, que uma filiação construída pelo amor (FUJITA, 2011).

Noutro giro, o artigo 42, parágrafo $6^{\circ}$ do Estatuto da Criança e do Adolescente, prevê o deferimento da adoção póstuma, quando há o falecimento do adotante no curso do procedimento da adoção.

A jurisprudência, no entanto, passou a admitir a adoção póstuma mesmo quando o procedimento judicial da adoção não tenha sido iniciado, quando comprovada a inequívoca manifestação de vontade do adotante, e comprovado

\footnotetext{
${ }^{4} \mathrm{O}$ artigo 1.593 do Código Civil de 2002 dispõe que: "O parentesco é natural ou civil, conforme resulte de consangüinidade ou outra origem".
} 
através de acontecimentos que ratifiquem essa manifestação de vontade (DIAS, 2011). Para Maria Berenice Dias (2011, p. 296):

ora, no momento em que é admitida a possibilidade da adoção, mesmo que não tenha o adotante dado início ao respectivo processo, às claras se está aceitando o reconhecimento da paternidade afetiva. Até porque é isso que a sentença faz. Flagrada a existência da posse de estado de filho, ou melhor, da posse de estado de pai, é declarado o vínculo de filiação por adoção.

Com essas colocações, percebe-se que o vínculo socioafetivo tem sido cada vez mais protegido pelo ordenamento jurídico, seja através de jurisprudências, enunciados das Jornadas de Direito Civil ou estruturações doutrinárias.

A parentalidade socioafetiva, apresenta-se em diversas situações, como na posse de estado de filho, representada pela adoção à brasileira e pelo filho de criação; nas técnicas de reprodução assistida heteróloga, que são aquelas em que há material genético de terceiro; e também na adoção legal.

Quanto à posse de estado de filho ${ }^{5}$, compreendem-se, doutrinariamente, três aspectos para o seu reconhecimento, a nominatio - usar e se apresentar com o nome da família; tractatus - ser tratado como filho, educado, criado como tal; e reputatio - ser conhecido como filho de forma notória perante a sociedade. (DIAS, 2011).

O Código Civil prevê em seu artigo 1.605, inciso II, a posse de estado de filho como meio de prova no caso de ausência de parentalidade no registro de nascimento.

Porém, Luiz Edson Fachin (1996) menciona outras funções para a posse de estado: a de criação e de estabelecimento de uma relação de filiação.

O que se busca, é abrigar juridicamente uma situação que de fato já existe, uma verdade tanto no plano exterior, quanto no interior, traduzida no querer intrínseco de ser pai, mãe ou filho.

A adoção à brasileira é exemplo clássico da posse de estado de filho, pois

\footnotetext{
${ }^{5}$ No IX Congresso Brasileiro de Direito de Família, realizado em Araxá/MG em 22 de novembro de 2013, o Instituto Brasileiro de Direito de Família (IBDFAM) aprovou o Enunciado Programático n 7 : “ A posse de estado de filho pode constituir a paternidade e maternidade".
} 
consiste no fato de uma pessoa registrar uma criança como sendo seu filho, mesmo sabendo não se tratar de uma verdadeira filiação biológica, sem obedecer os trâmites legais (FUJITA, 2011).

Ocasiona reflexos criminais, segundo artigo 242 do Código Penal Brasileiro, que preceitua:

Art. 242 - Dar parto alheio como próprio; registrar como seu o filho de outrem; ocultar recém-nascido ou substituí-lo, suprimindo ou alterando direito inerente ao estado civil:

Pena - reclusão, de dois a seis anos.

Parágrafo único - Se o crime é praticado por motivo de reconhecida nobreza:

Pena - detenção, de um a dois anos, podendo o juiz deixar de aplicar a pena.

Esse dispositivo é de ação múltipla, apresentando diversas figuras típicas. Quando se trata da segunda, qual seja, registrar como seu filho de outro, raramente alguém é condenado, eis que na maioria dos casos, fica evidenciado que o agente agiu com generosidade ou afeto, visando criar e educar a criança, sendo assim aplicado o perdão judicial, com base no parágrafo único do dispositivo em comento (GONÇALVES, 2011).

Um dos exemplos de adoção à brasileira é quando o namorado ou marido da mãe registra voluntariamente o filho da companheira como sendo seu filho, mesmo sabendo não se tratar da realidade biológica da criança.

Já os "filhos de criação" são aqueles que apesar de não serem filhos biológicos e não serem registrados como tal são tratados e reconhecidos como se filhos fossem. Encontram-se sob a guarda de fato dos "pais de criação", e não sob o amparo de uma adoção legal, o que não os equipara juridicamente às demais filiações, causando-Ihes prejuízos (FUJITA, 2011).

Sobre os filhos nascidos das técnicas de reprodução assistida heteróloga, em que se utilizam material genético de um doador, o artigo 1.597, inciso $\mathrm{V}$ do Código Civil prevê a presunção de serem concebidos na constância do matrimônio, desde que tenha prévia autorização do marido.

As técnicas de reprodução assistidas são utilizadas em casos de infertilidade do casal, ou de um de seus membros. A filiação não pode ser impugnada pelo pai 


\section{VIANNASAPIENS}

edição especial

Juiz de Fora - 2014

que não cedeu seu material genético, tendo em vista que quando a gestação já está em andamento a autorização não admiti retratação, não servindo a prova da inexistência do liame biológico (DIAS, 2011).

Desta feita, como assinala Silmara Juny Chinelato, 2004 (apud DIAS, 2011, p. 369) "trata-se de presunção absoluta de paternidade socioafetiva".

Já a adoção legal é aquela pela qual mediante sentença judicial transitada em julgado é estabelecido um vínculo entre adotante(s) e adotado, sem que exista entre eles relação de parentesco genético. Tem previsão no artigo 1.618 e no artigo 1.619 do Código Civil; e nos artigos 39 a 52-D do Estatuto da Criança e do Adolescente.

Observa-se na adoção uma forma clara de filiação socioafetiva, tendo em vista que os adotantes se colocam na condição de pai ou mãe por escolha própria e pelo vínculo de afeto, que é estabelecido entre eles e o adotado durante o período de convivência ou quando detinham a guarda do menor.

No que tange aos efeitos da filiação socioafetiva ${ }^{6}$, Maria Berenice Dias (2011, p. 374) aduz:

o reconhecimento da paternidade ou da maternidade socioafetiva produz todos os efeitos pessoais e patrimoniais que the são inerentes. O vínculo de filiação socioafetiva, que se legitima no interesse do filho, gera o parentesco para todos os fins de direito, nos limites da lei civil.

Desta forma, a paternidade ou maternidade baseada no afeto gera também o dever de prestar alimentos, conforme preceitua o enunciado no 341 da IV Jornada de Direito Civil "para os fins do art. 1.696, a relação socioafetiva pode ser elemento gerador de obrigação alimentar".

Quanto ao reconhecimento da parentalidade socioafetiva, o Superior Tribunal de Justiça vem

Outrossim, importa assinalar que hoje se fala em uma nova modalidade de espécie de filiação, a chamada paternidade alimentar.

\footnotetext{
${ }^{6}$ O IBDFAM também aprovou no IX Congresso Brasileiro de Direito de Família, o Enunciado Programático $n^{\circ} 6$ que estabelece que: "Do reconhecimento jurídico da filiação socioafetiva decorrem todos os direitos e deveres inerentes à autoridade parental."
} 
Versa a mencionada paternidade, que o pai biológico tem a obrigação de prestar alimentos ao filho, mesmo quando há um pai socioafetivo, contanto que o pai socioafetivo não disponha de condições financeiras adequadas para manter o sustento do filho de forma satisfatória (MADALENO, 2013).

Nesse sentido Rolf Madaleno (2013) sustenta que:

\begin{abstract}
neste contexto, exonerar o genitor biológico do auxílio alimentar de seu filho genético apenas porque está vinculado a um parentesco socioafetivo seria permitir o duplo empobrecimento, moral e material do descendente genético, que deve usufruir de uma melhor condição socioeconômica em conformidade com aquela desfrutada por seu procriador. Cumpre o pai socioafetivo do jeito que pode e nos limites de suas condições financeiras arcar com o que dispõe para a formação, alimentação e educação do rebento que assumiu o amor.
\end{abstract}

Sobre a paternidade alimentar, Pablo Stolze Gagliano e Rodolfo Pamplona Filho (2013, p. 641) advertem que "parece razoável aplicá-lo em situações de rejeição da filiação, e em que haja imperiosa necessidade econômica, aliada a ausência de recursos do pai socioafetivo".

A obrigação alimentar imposta ao genitor biológico não ocasiona a inserção do filho na família biológica, não importando em desconstituição do registro do pai socioafetivo (MADALENO, 2013).

O pai socioafetivo continua sendo pai e o biológico é pai somente no que consiste no dever de sustento, tendo em vista que como Rolf Madaleno (2013) expõe, o pai de sangue não pode ser " compensado com a dispensa da sua responsabilidade pelo vínculo de sua procriação, apenas porque outro assume por afeto a sua primitiva função parental".

Feitas essas considerações, importa assinalar que o afeto se tornou um norteador para as relações jurídicas familiares, pretendendo assim, privilegiar a realidade fática em prol do melhor interesse da criança e do adolescente, da dignidade da pessoa humana e da solidariedade.

Todavia, as presunções estabelecidas pelo ordenamento jurídico e o liame biológico não são, e não podem ser completamente excluídos quando se analisa os 
elos de parentalidade, tendo em vista que nem sempre a afetividade está presente nas relações filiais.

\section{A INELEGIBILIDADE DO FILHO SOCIOAFETIVO}

A Constituição Brasileira de 1988 invoca em seu artigo 14, parágrafo 7ํㅡ, a inelegibilidade para cargos políticos do cônjuge e dos parentes consanguíneos ou afins ou por adoção do antecessor político. Assim vejamos:

são inelegíveis, no território de jurisdição do titular, o cônjuge e os parentes consanguíneos ou afins, até o segundo grau ou por adoção, do Presidente da República, de Governador de Estado ou Território, do Distrito Federal, de Prefeito ou de quem os haja substituído dentro dos seis meses anteriores ao pleito, salvo se já titular de mandato eletivo e candidato à reeleição.

Nessa seara, percebe-se que o estado de filiação não gera efeitos somente no âmbito do Direito de Família e Sucessões, pois gera efeitos também em outros ramos do Direito, como no caso, no Direito Eleitoral (TEIXEIRA, 2013).

O Tribunal Regional Eleitoral do Piauí (TRE-PI) em 10 de novembro de 2009, julgou o Recurso Contra Expedição de Diploma no 10 (RCED) em que foi alegado a inelegibilidade do prefeito eleito, com fundamento no artigo $14, \S 7^{\circ}$ da Carta Magna, por ser filho socioafetivo do ex-prefeito do município de P’Árco do Piauí/PI. O Tribunal rejeitou a preliminar, e no mérito, deu provimento ao recurso contra a expedição do diploma, para desconstituir os diplomas do prefeito e do vice-prefeito e determinou a eleição dos segundos candidatos, ora recorrentes.

No caso os recorrentes alegaram que o candidato eleito era inelegível, pois, em que pese não haver uma adoção formal, o recorrido sempre foi tratado publicamente como filho, sendo caso de uma adoção de fato, existindo inclusive cartaz anterior que constava a foto do prefeito eleito e a seguinte frase: "O prefeito de P'Arco do Piauí e seus filhos desejam à população um feliz natal" (TRE-PI, 2009, p.4).

Como o ex-prefeito, pai socioafetivo, já tinha sido reeleito e não renunciou o 
cargo, haveria assim a vedação expressa na Constituição Federal e no artigo 1 $3^{\circ}$ da LC n64/90, para a eleição do recorrido. Versa a ementa do acórdão do TRE-PI (2009, p.1):

Recurso Contra Expedição de Diploma. Relação socioafetiva comprovada. Filho de criação. Incidência do art. $14, \S 7^{\circ}, \mathrm{CF} / 88$. Inelegibilidade constitucional comprovada.

1. Abuso do poder econômico e politico não provado.

2. Comprovada a relação socioafetiva de filho de criação do prefeito eleito em relação ao seu antecessor, impõese a aplicação da inelegibilidade prevista no art. $14, \S 7^{0}$ da Constituição Federal c/c art. 262, inciso I, do Código Eleitoral, com a desconstituição dos mandatos do prefeito e do vice-prefeito.

3. Recurso Provido.

Com o provimento do recurso, sobreveio o Recurso Especial no 5410103.2008.6.18.0032 (REsp) no Tribunal Superior Eleitoral (TSE). Os recorrentes sustentaram no Recurso Especial, que o Tribunal Superior já teria decidido em julgamento anterior, que a adoção de fato não ensejaria a inelegibilidade prevista na Constituição Federal, violando a segurança jurídica e que o Tribunal Regional interpretou a vedação de forma extensiva (TSE, 2011, p.3).

Em seu voto o Senhor Ministro Arnaldo Versiani (2011, p. 6) brilhantemente afirmou que o Direito não pode desconhecer a relação socioafetiva, e que "ao se admitirem os direitos oriundos da filiação socioafetiva, reconhecem-se também todos os deveres inerentes ao parentesco, inclusive para as hipóteses de inelegibilidade".

Quanto à alegação da interpretação extensiva, o Ministro Presidente Ricardo Lewandowski (2011, p.15) atentou para o fato de o Tribunal Regional não ter feito uma interpretação extensiva do dispositivo constitucional, mas sim uma interpretação teleológica, tendo em vista que os constituintes estabeleceram essa vedação com o escopo de "evitar a formação de oligarquias, o continuísmo, o compadrio, a perpetuação de famílias num determinado cargo". O Ministro (2011, p.16) concluiu também em seu voto que: 
consanguíneo pelos especialistas em Direito Civil, inclusive pelo próprio Conselho de Justiça Federal, a partir de enunciados elaborados com base em conclusões tiradas das chamadas Jornadas de Direito Civil.

Desta feita, o Tribunal Superior Eleitoral (2011, p.1) decidiu por voto majoritário, negar o recurso interposto, com a seguinte ementa:

RECURSO CONTRA EXPEDIÇÃO DE DIPLOMA. ADOÇÃO DE FATO. INELEGIBILIDADE.

1. Para afastar a conclusão do TRE/PI, de que ficou comprovada a relação socioafetiva de filho de criação de antecessor ex-prefeito, seria necessário o revolvimento do acervo probatório, inviável em sede de recurso especial, a teor da Súmula no 279 do Supremo Tribunal Federal.

2. O vínculo de relações socioafetivas, em razão de sua influência na realidade social, gera direitos e deveres inerentes ao parentesco, inclusive para fins da inelegibilidade prevista no $\S 7^{\circ}$ do art. 14 da Constituição Federal.

3. A inelegibilidade fundada no art. 14, $\S 7^{\circ}$, da Constituição Federal pode ser arguida em recurso contra a expedição de diploma, por se tratar de inelegibilidade de natureza constitucional, razão pela qual não há falar em preclusão.

Recurso não provido.

O acórdão abordado, de forma acertada, considerou que o reconhecimento da filiação socioafetiva gera também deveres inerentes ao estado de filho, como no caso a inelegibilidade fundada no parentesco.

Entretanto, não se pode esquecer que ao gerar a dita inelegibilidade, tem que ser assegurado também ao filho socioafetivo todos os efeitos jurídicos da relação paterno-filial, tanto na esfera familiar como na sucessória, o que não foi analisado no acordão, como bem observou Girard (2011, p. 114):

a questão, portanto, que também aqui se coloca é da amplitude dos efeitos do reconhecimento da filiação, para que ela não seja tomada somente sob um dos ângulos do instituto - como parece ter sido a solução dada ao caso em comento, onde o estado de filiação foi estabelecido sob a perspectiva pública, sem que ficasse asseverada a extensão dos direitos e reflexos jurídicos dessa filiação na âmbito e no seio da família adotiva. 
Posteriormente, na Ação Cautelar no $2.891(A C)^{7}$ interposta no Supremo Tribunal Federal, com medida cautelar de requerimento de liminar para atribuição de efeito suspensivo a recurso extraordinário, o Ministro relator Luiz Fux indeferiu a liminar.

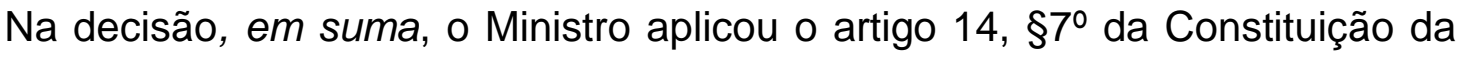
República às hipóteses de filiação socioafetiva sob interpretação teleológicasistêmica da Constituição Federal, não violando a segurança jurídica, e não reconheceu os requisitos legitimadores da concessão da medida cautelar sem a oitiva da parte contrária (STF, 2011).

Desta feita, ficou demonstrado que o reconhecimento jurídico da filiação socioafetiva traz consigo importantes consequências, não só no âmbito pais e filho, mas também para toda a sociedade, como na aplicação da inelegibilidade para os filhos socioafetivos.

\section{O ALCANCE DA LEI 11.924/2009}

Nas palavras de Paplo Stolze Gagliano e Rodolfo Pamplona Filho (2006, p. 135) os direitos da personalidade são "aqueles que têm por objeto os atributos físicos, psíquicos e morais da pessoa em si e em suas projeções sociais". E como classifica Tartuce (2011, p. 86):

os direitos da personalidade são tidos como intransmissíveis, irrenunciáveis, extrapatrimoniais e vitalícios, eis que comuns à própria existência da pessoa. Tratam-se ainda de direitos subjetivos, inerentes à pessoa (inatos), tidos como absolutos, indisponíveis, imprescritíveis e impenhoráveis.

O nome, sendo um dos direitos da personalidade possui todas estas características, e é contemplado nos artigos 16 a 19 do Código Civil de 2002.

De acordo com o artigo 16 do Código Civil o direito de ter um nome é assegurado a todos, e é composto por prenome, que é o nome próprio da pessoa, e

\footnotetext{
7 STF- AC 2891 MC, Relator(a): Min. Luiz Fux, julgado em 06/06/2011, publicado em processo eletrônico DJe-115 DIVULG 15/06/2011 PUBLIC 16/06/2011.
} 
sobrenome (apelido, patronímico, nome de família).

Oliveira (2013) expõe que "o nome da pessoa constitui fator de sua identificação no meio familiar e social".

No sentido de dar equivalência ao nome constante no registro e a realidade de fato, foi aprovada a Lei 11.924 de 17/04/2009. A Lei acrescentou ao artigo 57 da Lei de Registros Públicos, Lei $6.015 / 73^{8}$, o parágrafo $8^{\circ}{ }^{9}$, autorizando o enteado ou a enteada, havendo motivo ponderável, a acrescentar ao seu nome, o nome de família do padrasto ou da madrasta, desde que com sua anuência, sem prejuízo dos apelidos dos genitores.

Para Carvalho (2012, p.120) "a abordada Lei possibilita que se consubstancie no Registro Civil da pessoa o nome que corresponda exatamente a sua realidade familiar".

Importante se faz citar a justificativa apresentada pelo Deputado Clodovil Hernandes, no Projeto de Lei (PL) 207 de 15 de fevereiro de 2007 que originou a Lei em comento:

o presente projeto de lei vem em socorro daquelas centenas de casos que vemos todos os dias, de pessoas em seu segundo ou terceiro casamento, criam os filhos de sua companheira como se seus próprios filhos fossem. Essas pessoas dividem uma vida inteira e, na grande maioria dos casos, têm mais intimidade com o padrasto do que com o próprio pai, que acabou por acompanhar a vida dos filhos à distância. É natural, pois, que surja o desejo de trazer em seu nome o nome de família do padrasto.

Ao autorizar a averbação do nome de família do companheiro (a) do pai ou da mãe, a Lei realça a importância do reconhecimento da afetividade entre aqueles que mesmo sem os laços de sangue se comportam como se fossem pais e filhos.

\footnotetext{
8 Artigo 57 da Lei 6.015/73 que: "A alteração posterior de nome, somente por exceção e motivadamente, após audiência do Ministério Público, será permitida por sentença do juiz a que estiver sujeito o registro, arquivando-se o mandado e publicando-se a alteração pela imprensa, ressalvada a hipótese do art. 110 desta Lei."

${ }^{9} \S 8^{\circ}$ do artigo 57 da Lei 6.015/73: "O enteado ou a enteada, havendo motivo ponderável e na forma dos $\S \S 2^{\circ}$ e $7^{\circ}$ deste artigo, poderá requerer ao juiz competente que, no registro de nascimento, seja averbado o nome de família de seu padrasto ou de sua madrasta, desde que haja expressa concordância destes, sem prejuízo de seus apelidos de família."
} 


\section{VIANNA SAPIENS}

edição especial

Juiz de Fora - 2014

É necessário, todavia, uma análise cautelosa pelo juiz, como elucida Carvalho (2012, p. 123):

[...] na qual seja averiguado se o (a) enteada e o padrasto ou madrasta têm real vontade de compartilharem o mesmo sobrenome e, a princípio, para sempre, porque toda adoção do sobrenome não deve ser forçada nem provisória, impulsionada por motivos interesseiros, mas realizada em benefício do bem-estar da pessoa do (a) enteado, a qual irá portá-la.

Cumpre salientar que a Lei autoriza apenas a acrescentar o sobrenome do companheiro (a) da mãe ou do pai, não alterar o estado de filiação. No entanto, conforme entendimento de Oliveira (2013) " [...] a adoção do nome do afim na linha reta é meio caminho para o eventual futuro pleito judicial de reconhecimento de uma filiação sócio-afetiva".

E por não haver a exclusão dos nomes de família dos pais registrais, Carvalho (2012, p.122) assevera que:

não se desconstitui, portanto, a paternidade ou maternidade registral, de modo que se pode dizer que a lei já começa a engatinhar no reconhecimento legal da coexistência de dois pais ou duas mães em relação a uma pessoa, bem como da filiação socioafetiva.

Portanto, pode-se perceber que ao autorizar a averbação do nome de família do companheiro (a) do pai (mãe), a Lei realça a importância do reconhecimento da afetividade entre aqueles que mesmo sem os laços de sangue se comportam como se fossem pais e filhos, sendo um caminho para o reconhecimento da filiação socioafetiva e para a multiparentalidade.

\section{A PREDOMINÂNCIA DA FILIAÇÃO SOCIOAFETIVA SOBRE A FILIAÇÃO BIOLÓGICA COMO REPERCUSSÃO GERAL}

A predominância ou não da filiação socioafetiva, é tema com repercussão geral, conforme foi reconhecido pelo Supremo Tribunal Federal (STF).

Segundo Humberto Theodoro Júnior (2010, p. 651): 


\section{VIANNA SAPIENS}

edição especial
z de Fora - 2014

por repercussão geral, a lei entende aquela que se origina de questões 'que ultrapassem os interesses subjetivos da causa', por envolver controvérsias que vão além do direito individual ou pessoal das partes. É preciso que, objetivamente, as questões repercutam fora do processo e se mostrem 'relevantes do ponto de vista econômico, político, social ou jurídico'”.

$\mathrm{Na}$ ação que originou o Recurso Extraordinário com Agravo (ARE) nº 692186PB, a autora requereu o reconhecimento da filiação biológica e a anulação do registro de nascimento, pois foi registrada como filha de seus avós paternos. Em primeira instância os pedidos foram julgados procedentes pela $2^{\underline{a}}$ Vara de Família de Campina Grande. Inconformados, os réus apelaram para o Tribunal de Justiça da Paraíba, sustentando a decadência do direito da autora, com fulcro no artigo 362 do Código Civil de 1916 repetido no atual Código no artigo 1.614; a existência de uma filiação socioafetiva da autora com os pais registrais; e a finalidade da propositura da ação, que visava receber dupla herança, eis que já agraciada pela herança dos seus pais registrais (TRIBUNAL DE JUSTIÇA DA PARAÍBA, 2009).

No que concerne à alegação da decadência do direito da filha de impugnar sua filiação, previsto no artigo 1.614 do Código Civil, a relatora Maria das Graças Fernandes Duarte (2009, p. 8), entendeu que não há prazo decadencial em ação ajuizada pela filha natural, conforme trecho do voto proferido no acordão:

[...] no caso dos autos, trata-se de ação intentada por filha que pretende restabelecer seu vínculo biológico com seu pai (falecido), razão pela qual, não há que se falar na incidência do art. 362 do CC/16, cuja aplicação deve ser restrita aos casos de Ação Investigatória ajuizada pelo genitor ou genitora, onde se permite ao filho maior ser reconhecido apenas com o seu consentimento, e ao filho menor, impugnar o reconhecimento, quando atingida à maioridade."

Quanto à alegação da filiação socioafetiva, a relatora $(2009$, p.9) afirmou que a aplicação de tal filiação não pode ser levada em consideração quando é o filho natural que busca a identidade biológica. Deixou de se manifestar sobre alegação da possibilidade de herdar de forma dupla (2009, p. 10).

Diante de tais considerações, o Tribunal de Justiça da Paraíba (2009), de forma unânime, deu provimento parcial ao recurso apenas para reduzir os 


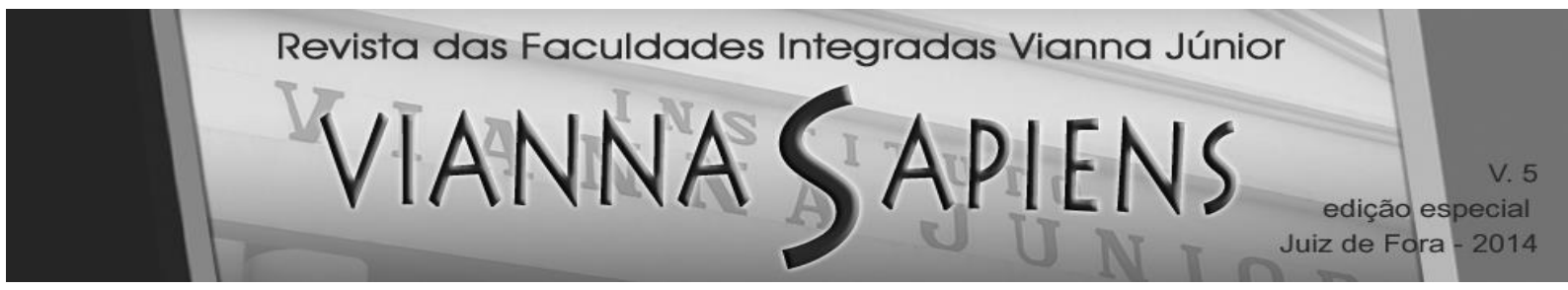

honorários advocatícios, mantendo inalterada os demais termos da r. sentença. ${ }^{10}$

Os recorrentes buscaram a reforma do mencionado acórdão no Superior Tribunal de Justiça (STJ), através do Recurso Especial no 1.203.874/PB (2011). O STJ negou seguimento ao recurso, por entender que se tratando de adoção à brasileira, o filho adotado pode buscar a qualquer tempo a nulidade do registro e o estabelecimento da filiação biológica, mesmo quando presente o vínculo socioafetivo com os pais registrais (STJ, 2011). ${ }^{11}$ O STJ negou também seguimento ao Recurso Extraordinário (STF, 2012). ${ }^{12}$

A questão controvertida, então, chegou ao STF através do ARE № 692186$\mathrm{PB}$, no qual, os recorrentes alegaram, em suma, que a decisão do STJ afrontou o artigo 226 da Constituição Federal, pois não priorizou as relações baseadas no afeto, preferindo a realidade biológica em detrimento da realidade socioafetiva.

O Ministro relator Luiz Fux (2012, p. 2) reconheceu a repercussão geral do tema, por ser relevante sob os pontos de vista jurídico, social e econômico, e submeteu a matéria aos outros Ministros do STF ${ }^{13}$. Sobre a decisão, em entrevista para o site do Instituto Brasileiro de Direito de Família (IBDFAM), o presidente do IBDFAM do Paraná, Rodrigo Toscano de Brito (2013) assinalou que:

[...] do ponto de vista estritamente jurídico, há uma discussão sobre os efeitos das relações de família que se formam a partir de laços afetivos, ou seja, efeitos sobre direito patrimonial, da personalidade, registral, entre outros, reforçando, inclusive as teses do IBDFAM. um ponto interessante, aliás, é esse da nulidade do registro: por que anular um registro se ele, inclusive, retrata uma realidade fática de filiação socioafetiva? Esse é um tema de repercussão geral, até mesmo porque o registro público deve ser um espelho das situações fáticas vividas pelas pessoas e não um elemento que esconda uma realidade, especialmente de afeto.

10 TJPB - Processo no 00120050311099003 - Órgão (3a Câmara Cível) - Relator Dra. Maria das Graças Fernandes Duarte - Juíza convocada - j. em 07/07/2009.

${ }_{11}$ STJ - Recurso Especial no 1.203.874 - PB (2010/0133365-0) - Ministro Massami Uyeda, Data da Publicação: 08/04/2011.

${ }^{12}$ STJ - RE nos EDcl no AgRg no Recurso Especial № 1.203.874 - PB (2010/0133365-0) - Ministro Felix Fischer, Data da Publicação: 01/03/2012.

${ }^{13}$ STF-ARE 692186 RG, Relator(a): Min. Luiz Fux, julgado em 29/11/2012, processo eletrônico DJe034 divulg 20-02-2013 public 21-02-2013. 


\section{VIANNA SAPIENS}

edição especial

Juiz de Fora - 2014

De acordo com o entrevistado no caso em análise pelo STF ficou concretizada a filiação socioafetiva, que, inclusive, ocasionou o recebimento de herança por parte da filha. Não se pode assim, enfatizar somente o vínculo biológico, como se a relação afetiva não tivesse importância. Está se confundindo o assunto com a imprescritibilidade de se conhecer a ascendência genética, um dos direitos da personalidade, que por ser tratar de ação de estado, é imprescritível (IBDFAM, 2013).

Quando em ação de investigação de paternidade ou maternidade busca-se também desconstituir o vínculo formado pelos pais registrais, Maria Berenice Dias (2011, p. 391) afirma que:

sempre que o autor tiver pai registral ou houver indícios de uma filiação consolidada por um vínculo afetivo, dilata-se o objeto da demanda. Além da identificação da verdade biológica, é necessário que fique comprovada a não existência de vínculo de filiação gerador da posse de estado de filho.

O IBDFAM foi aceito como Amicus Curiae na ação em comento, que até a presente data ainda não foi julgada (IBDFAM, 2013).

Com o julgamento da ação, o STF pode estabelecer uma interpretação atualizada do conceito jurídico de filiação, e inclusive levar em consideração o princípio que atualmente norteia as relações familiares, o princípio da afetividade.

\section{MULTIPARENTALIDADE E A FILIAÇÃO SOCIOAFETIVA}

De acordo com Pablo Stolze Gagliano e Rodolfo Pamplona Filho (2013, p. 644): "a visão tradicional sobre a filiação é no sentido de que o seu reconhecimento resultaria em uma dual perspectiva de parentalidade (em primeiro grau): o (os) filho (os) vincula-se a um pai e uma mãe".

Todavia, os autores ponderam que "[...] com a admissão de novas formas de composição familiar, não seria hora de rever esse aparente dogma?" [...] "será que não é o momento de se amparar, juridicamente, a situação - muitas vezes ocorrente 
- de um filho possuir dois pais ou duas mães?" (GAGLIANO; PAMPLONA FILHO, 2013, p.644).

Para Tartuce (2013, p.4) “ o que se tem visto na jurisprudência até aqui é uma escolha de Sofia, entre o vínculo biológico e o socioafetivo, o que não pode prosperar em muitas situações fáticas."

Com o reconhecimento cada vez mais frequente da filiação socioafetiva, é necessário atentar para as situações em que o vínculo biológico também não merece ser desconstituído. E assim, algumas decisões têm considerado a multiparentalidade, que nas palavras de Pablo Stolze Gagliano e Rodolfo Pamplona Filho (2013, p. 644) é a "situação em que um indivíduo tem mais de um pai e/ou mais de uma mãe, simultaneamente, produzindo-se efeitos jurídicos em relação a todos eles".

Destaca-se a decisão da Vara Judicial da Comarca de Ariquemes, Estado de Rondônia, nos autos no 0012530-95.2010.8.22.0002 (2012) que, em demanda de investigação de paternidade cumulada com anulatória de registro, decidiu pelo reconhecimento da multiparentalidade.

A demanda tratou de caso de adoção à brasileira, em que a representante da menor requereu a anulação do registro, para lançar no documento o nome do pai biológico da filha (VARA JUDICIAL DA COMARCA DE ARIQUEMES DOESTADO DE RONDÔNIA, 2012).

A juíza Deisy Cristhian Lorena de Oliveira Ferraz (2012), através de provas colhidas durante toda instrução, observou o forte vínculo que a criança tinha com o pai registral, percebendo que o pai exercia a paternidade socioafetiva e que não pretendia desconstituí-la. Ademais, percebeu que após o resultado positivo do exame de DNA com o pai biológico, a criança começou a conviver com o mesmo e com sua família. E o pai biológico expressou sua vontade em reconhecer a menor como filha.

Desta feita, a juíza (2012, p. 4) decidiu pela coexistência dos dois vínculos paternos: 


\section{VIANNAS SAPIENS}

edição especial

diante de todo exposto e a singularidade do caso, é mister considerar a manifestação de vontade da autora no sentido de que possui dois pais, aliado ao fato que o requerido [...] não deseja negar a paternidade socioafetiva e o requerido [...] pretende reconhecer a paternidade biológica, e acolher a proposta ministerial de reconhecimento da dupla paternidade registral da autora.

Outra decisão que merece destaque é a que foi proferida pela 1a Câmara de Direito Privado do Tribunal de Justiça do Estado de São Paulo na Apelação Civil no 0006422-26.2011.8.26.0286 (2012), em ação declaratória de maternidade socioafetiva c/c retificação do assento de nascimento, que decidiu pelo provimento do recurso, para consta a multiparentalidade. ${ }^{14}$

A ação em $1^{\text {a }}$ instância foi julgada parcialmente procedente, apenas para incluir no assento de nascimento do requerente, o sobrenome da coautora, no entanto, foi afastado o reconhecimento da filiação socioafetiva (TJSP, 2012).

No caso, a mãe biológica da menor faleceu poucos dias após seu nascimento, e algum tempo depois, o pai da criança veio a se casar com outra mulher, que exerceu o papel de mãe da menor, tendo o vínculo socioafetivo sido plenamente demonstrado nos autos (TJSP, 2012).

O recurso foi julgado procedente com a seguinte ementa (TJSP, 2012, p. 2):

EMENTA: MATERNIDADE SOCIOAFETIVA - Preservação da Maternidade Biológica - Respeito à memória da mãe biológica, falecida em decorrência do parto, e de sua família - Enteado criado como filho desde dois anos de idade Filiação socioafetiva que tem amparo no art. 1.593 do Código Civil e decorre da posse do estado de filho, fruto de longa e estável convivência, aliado ao afeto e considerações mútuos, e sua manifestação pública, de forma a não deixar dúvida, a quem não conhece, de que se trata de parentes - A formação da família moderna não-consanguínea tem sua base na afetividade e nos princípios da dignidade da pessoa humana e da solidariedade Recurso provido.

Outrossim, na mesma linha, tem-se o julgado da Vara Judicial da Comarca de São Francisco de Assis/RS, analisado pela assessoria de comunicação do IBDFAM (2013). A decisão foi pela inclusão do nome da mãe socioafetiva no registro de

\footnotetext{
${ }^{14}$ TJSP - Apelação oo 000622-26.2011.8.26.0286 - Relator: Min. Alcides Leopoldo e Silva Júnior, Data da Publicação: 23/08/2012.
} 
nascimento de duas crianças, estando presente assim, a multiparentalidade. As crianças perderam a mãe biológica muito cedo e estabeleceram com a companheira do pai um vínculo materno, socioafetivo, deste modo ajuizaram ação declaratória de maternidade socioafetiva, sem excluir o nome da genitora da certidão de nascimento (IBDFAM, 2013).

A juíza, 2013 (apud IBDFAM, 2013) assegurou que o pedido inicial não significa impossibilidade jurídica do pedido, " afinal, não são os fatos que se amoldam às leis, mas sim, estas são criadas para regular as consequências que advêm dos fatos, objetivando manter a ordem pública e a paz social". E ainda, observou que "é preciso amadurecimento da sociedade para que se exija uma conduta ativa dos legisladores a ponto de regulamentarem matérias polêmicas".

A par destas colocações, percebe-se que acertadamente o judiciário já tem decidido pela coexistência dos dois vínculos, o biológico e o socioafetivo, produzindo efeitos jurídicos para todos eles ${ }^{15}$, no caso do filho possuir um (uma) pai (mãe) socioafetivo (a), e, no entanto, possuir também efetivamente um pai (mãe) biológico (a). Assim, nas palavras de Pablo Stolze Gagliano e Rodolfo Pamplona Filho (2013, p. 644) estas decisões têm contribuído para a "ideia de família contemporânea plural".

\section{CONCLUSÃO}

Com a descoberta do exame de DNA, a filiação que antes era pautada exclusivamente em presunções jurídicas estabelecidas pelo ordenamento, passou a preferir o vínculo biológico. Contudo, com as mudanças sociais, econômicas e culturais ocorridas na sociedade e na legislação brasileira, foi verificado que esse elo genético nem sempre é apto a assegurar uma filiação responsável e verdadeira, baseada na dedicação, na ampla assistência. Assim, foi necessário reconhecer a

\footnotetext{
${ }^{15}$ Também foi aprovado pelo IBDFAM o Enunciado Programático $n^{\circ} 9$ estabelecendo que: "A multiparentalidade gera efeitos jurídicos."
} 
paternidade ou maternidade baseada na convivência, no afeto, no cuidado, a denominada filiação socioafetiva.

Pode-se constatar que a filiação socioafetiva ocasiona consequências também para outros ramos do direito, como no caso do Direito Eleitoral, onde a inelegibilidade prevista no artigo $14, \S^{\circ}$ da Constituição Federal alcança os filhos socioafetivos.

A Lei 11.924 de 17 de abril de 2009 que autorizou a averbação do sobrenome do padrasto ou madrasta no registro de nascimento do filho realçou ainda mais a importância do afeto nas entidades familiares, e demonstrou ser um caminho para uma futura ação de reconhecimento de filiação socioafetiva, ou para a multiparentalidade.

Outrossim, cumpre salientar a relevância do reconhecimento da filiação socioafetiva, eis que assegura aos filhos todos os direito e deveres inerentes do estado de filho. Observa-se também a importância do tema, tendo em vista que o Supremo Tribunal Federal reconheceu a repercussão geral da prevalência ou não da parentalidade socioafetiva. A decisão do Supremo Tribunal de Justiça pode estabelecer uma interpretação atualizada do conceito de filiação.

Por fim, percebe-se que em situações que o filho possui de fato dois pais ou duas mães, é necessário considerar uma corrente contemporânea do Direito de Família, a da multiparentalidade, na qual há a coexistência dos vínculos biológicos e socioafetivos, produzindo efeitos para todos eles. 


\title{
VIANNASAPIENS
}

edição especial

Juiz de Fora - 2014

\section{AFFECTIVE FILIATION AND THEIR REFLECTIONS IN THE BRAZILIAN LEGAL SYSTEM}

\begin{abstract}
The objective of this work is to analyze the relevance of the affective filiation and to talk about the reflections of its recognition in the Brazilian legal system. Because of the social changes that have happened in the families, the Family Law started to valorize the affecting relations between parents and kids, and started to recognize a new type of filiation, the affective filiation, which is not being ignored by the Law, even if it is still a reason of jurisprudence and doctrinal differences. Affective filiation is the one which is based on the family relation, on the solidarity, on the love among parents and kids, without necessarily existing biological or legal ties between them. This occurs in a lot of situations, as the adoption, the Brazilian adoption, raising children and children from the donation or heterologous assisted reproduction. The research was made through the study of theoretical doctrine, and jurisprudences about this theme. The recognition of affective filiation produces personal effects that go beyond the relationship of parents and kids, like in the case of ineligibility of the affective kid. The Federal Supreme Court has recognized the general repercussion of the prevalence of the affective kid theme. The creation of the Law 11.924/2009 which has authorized the addition of the patronymic stepparents in the birth registration is a reflex that the affective filiation has caused in the legislation. The multiple parents is a direction which has been used by the jurists with the purpose of giving effect to all kind of affective ties existing in the family.
\end{abstract}

KEY WORDS: FAMILY. FILIATION. AFFECTIVE. AFFECTION. MULTIPLE PARENTES. 


\section{VIANNA SAPIENS}

\section{REFERÊNCIAS}

BRASIL. Código Civil Brasileiro de 2002. In: AGNER, Anne Joyce (Org). Vade

Mecum Acadêmico de Direito. 16.ed. São Paulo: Rideel, 2013.

BRASIL. Código Penal Brasileiro de 1940. In: AGNER, Anne Joyce (Org). Vade Mecum Acadêmico de Direito. 16.ed. São Paulo: Rideel, 2013

BRASIL. Constituição da República Federativa do Brasil de 1988. In: AGNER, Anne Joyce(Org.). Vade Mecum Acadêmico de Direito. 16.ed. São Paulo: Rideel, 2013.

BRASIL. Estatuto da criança e do adolescente. In: AGNER, Anne Joyce (Org). Vade Mecum Acadêmico de Direito. 16.ed. São Paulo: Rideel, 2013.

BRASIL. Lei no 6.515/77 de 26 de dezembro de 1977. Disponível em: <http://www.planalto.gov.br/ccivil_03/leis/l6515.htm> Acesso em: 07/2013.

BRASIL. Congresso Nacional. Projeto de Lei no 207 de 15 de fevereiro de 2007. Disponível em:

<http://www.camara.gov.br/proposicoesWeb/prop_mostrarintegra?codteor=435432\&f ilename=PL+206/2007>. Acesso em: 09/2013.

BRASIL. Lei no 6.015 de 31 de dezembro de 1973. Disponível em: <http://www.planalto.gov.br/ccivil_03/leis/l6015.htm>. Acesso em: 07/2013.

BRASIL. Lei no 11.924 de 17 de abril de 2009. Disponível em:

<http://www.planalto.gov.br/ccivil_03/_Ato2007-2010/2009/Lei/L11924.htm>. Acesso em: 07/2013.

CARVALHO, Carmela Salsamendi de. Filiação socioafetiva e "conflitos" de paternidade e maternidade: A análise sobre a desconstituição do estado filial pautada no interesse do filho. Curitiba: Juruá, 2012.

CONSELHO DA JUSTIÇA FEDERAL. Enunciado 103, Enunciado 108. Disponível em:<http://www.stj.jus.br/publicacaoseriada/index.php/jornada/article/viewFile/2611/2 689>. Acesso em: 07/ 2013.

CONSELHO DA JUSTIÇA FEDERAL. Enunciado 256. Disponível em:<http://www.stj.jus.br/publicacaoseriada/index.php/jornada/article/viewFile/2619/2 696>. Acesso em: 07/2013.

CONSELHO DA JUSTIÇA FEDERAL. Enunciado 341. Disponível em:<http://www.stj.jus.br/publicacaoseriada/index.php/jornada/article/viewFile/2625/2 700>. Acesso em: 07/2013. 
DIAS, Maria Berenice. Manual de direito das famílias. 8.ed. São Paulo: Revista dos Tribunais, 2011.

FACHIN, Luiz Edson. Da paternidade: Relação biológica e afetiva. Belo Horizonte: Del Rey, 1996.

FUJITA, Jorge Shiguemitsu. Filiação. 2.ed. São Paulo: Atlas, 2011.

GAGLIANO, Pablo Stolze; PAMPLONA FILHO, Rodolfo. Novo curso de direito Civil: direito de família - As famílias em perspectiva constitucional. 3.ed. São Paulo: Saraiva, 2013.

GAGLIANO, Pablo Stolze PAMPLONA FILHO, Rodolf;. Novo curso de direito civil: Parte Geral. 8.ed. São Paulo: Saraiva, 2006.

GIRARD, Viviane. Inelegibilidade de Filho Socioafetivo. Revista Brasileira de Direito das Famílias e Sucessões, ano XIII, n. 23, 2011, p. 97-115.

GONÇALVES, Victor Eduardo Rios Gonçalves. Direito penal esquematizado: Parte Especial. São Paulo: Saraiva, 2011.

IBDFAM. Entrevista: filiação sociofativa, 2013. Disponível em: <http://www.ibdfam.org.br/noticias/4959/+Entrevista\%3A+Filia\%C3\%A7\%C3\%A30+s ocioafetiva>. Acesso em: 09/2013.

IBDFAM. TJRS entende que afeto se sobrepõe à lei em ação declaratória de maternidade socioafetiva, 2013. Disponível em:

<http://www.ibdfam.org.br/noticias/5108/TJRS++entende+que+afeto+se+sobrep\%C3 $\% \mathrm{~B} 5 \mathrm{e}+\% \mathrm{C} 3 \% \mathrm{~A} 0+\mathrm{lei}+\mathrm{em}+\mathrm{a} \% \mathrm{C} 3 \% \mathrm{~A} 7 \% \mathrm{C} 3 \% \mathrm{~A} 30+$ declarat $\% \mathrm{C3} \% \mathrm{~B} 3 \mathrm{ria}+\mathrm{de}+$ maternida de+socioafetiva\#.UkHWOtKkoTl>. Acesso em: 09/2013.

IBDFAM. STF aceita IBDFAM como amicus curiae em ação que discute a prevalência da paternidade socioafetiva sobre a biológica, 2013. Disponível em: < http://www.ibdfam.org.br/noticias/4974/novosite\#.UkO399KkoTk>. Acesso em 09/2013.

IBDFAM. Enunciados do IBDFAM são aprovados, 2013. Disponível em: <http://www.ibdfam.org.br/noticias/5194/Enunciados\%20do\%20IBDFAM\%20s\%C3\% A30\%20aprovados\#.Up8GtNJDs5A>. Acesso em 12/2013.

MADALENO, Rolf. Laços que fiam e paternidade alimentar. Disponível em: $<$ http://www.rolfmadaleno.com.br/novosite/conteudo.php?id=998>. Acesso em 08/2013.

OLIVEIRA, Euclides de. Enteado pode usar nome de padrasto. Disponível em: 
$<$ http://www.fernandatartuce.com.br/site/artigos/cat_view/38-artigos/44-artigos-deconvidados.html?start=10 >. Acesso em: 09/2013.

SUPERIOR TRIBUNAL DE JUSTIÇA. Recurso Especial nำ1.203.874- PB (2010/0133365-0), 2011. Disponível em:

<https://ww2.stj.jus.br/processo/jsp/revista/abreDocumento.jsp?componente=MON\&s equencial=14804085\&formato=PDF $>$. Acesso em: 09/2013.

SUPREMO TRIBUNAL FEDERAL. Recurso Extraordinário com agravo nํ692.186, 2012. Disponível em:

<http://redir.stf.jus.br/paginadorpub/paginador.jsp?docTP=TP\&doclD=3419008>. Acesso em: 09/2013.

SUPREMO TRIBUNAL FEDERAL. Ação Cautelar nº 2.891 MC/ PI- Piauí, 2011. Disponível em:

<http://www.stf.jus.br/portal/jurisprudencia/listarJurisprudencia.asp?s1=\%28AC\%24 \%2ESCLA\%2E+E+2891\%2ENUME\%2E\%29\&base=basePresidencia\&url=http://tiny url.com/aohcyxr>. Acesso em: 09/2013.

TARTUCE, Flávio. Manual de Direito Civil: Volume único. São Paulo: Método, 2011.

TARTUCE, Flávio. O princípio da afetividade no Direito de Família: Breves considerações. Disponível em <http://www.flaviotartuce.adv.br/index2.php?sec=artigos>. Acesso 09/2013.

TEIXEIRA, Guilherme Ribeiro. A filiação socioafetiva como hipótese de inelegibilidade prevista no artigo 14, § 7º, CF/88. Disponível em:

$<$ http://www.ambitojuridico.com.br/site/index.php?n_link=revista_artigos_leitura\&artig o_id=6486>. Acesso em: 09/2013.

THEODORO JÚNIOR, Humberto. Curso de Direito Processual Civil Volume I: teoria geral do direito processual civil e processo de conhecimento. 51.ed. Rio de Janeiro: Forense, 2010.

TRIBUNAL DE JUSTIÇA DA PARAÍBA. Apelação Cível e Agravo Retido no00120050311099003, 2009. Disponível em: <http://www.tjpb.jus.br/>. Acesso em: $09 / 2013$.

TRIBUNAL REGIONAL ELEITORAL DO ESTADO DO PIAUÍ. Recurso Contra Expedição de Diploma no 10, 2009. Disponível em:

$<$ http://www.tse.jus.br/sadJudInteiroTeor/pesquisa/actionGetTREBinary.do?tribunal= PI\&processoNumero $=10 \&$ processoClasse $=$ RCED\&decisaoData $=20091110 \&$ decisao Numero $=10 \&$ protocolo $=8782009 \&$ noCache $=0.7956752819009125>$. Acesso em: 09/2013. 
Revista das Faculdades Integradas Vianna Júnior

\section{VIANNA SAPIENS}

V. 5

edição especial

TRIBUNAL SUPERIOR ELEITORAL. Recurso Especial no 54101-03.2008.6.18.0032, 2011. Disponível em:

<http://www.tse.jus.br/sadJudInteiroTeor/pesquisa/actionGetBinary.do?tribunal=TSE \&processoNumero $=5410103$ \&processoClasse $=$ RESPE\&decisaoData $=20110215 \&$ de cisaoNumero $=\&$ protocolo $=\&$ noCache $=0.8456423182506114>$. Acesso em: 09/2013.

VARA JUDICIAL DA COMARCA DE ARIQUEMES DO ESTADO DE RONDÔNIA. Processo no 0012530-95.2010.8.22.0002, 2012. Disponível em: http://www.flaviotartuce.adv.br/jurisprudencias/201204031216120.MULTIPARENTAL IDADE_SENTENCARO.PDF. Acesso em: 09/ 2013. 